\title{
The Development of Authentic Assessment to Improve Students' Speaking Skills in Integration with Technology in Tourism Vocational High School
}

\author{
Suparmi $^{1}$, Afnesha Noveriana Chang ${ }^{2 *}$ \\ ${ }^{1,2}$ Fakultas Keguruan dan Ilmu Pendidikan, Universitas Putra Indonesia YPTK Padang \\ *afnesha_noverianachang@upiyptk.ac
}

\begin{abstract}
West Sumatra is currently known as one of the halal tourist destinations where tourists from all over the world come to visit. At the end of 2018, data from the Central Statistics Agency stated that the number of foreign tourists who came to West Sumatra via Minangkabau International Airport (BIM) reached approximately 5,094 people. For this reason, graduates of the Tourism Vocational School who will be one of the driving forces in this sector are expected to have English speaking skills that focus on the areas of expertise they take. So, an authentic English for Tourism Purposes (ETP) assessment model is needed to achieve maximum learning outcomes. The purpose of this study is to develop an authentic assessment model that is integrated with technology for the speaking skills of the Tourism Vocational School students. This study used needs analysis by distributing online questionnaire to collect the data. The samples of this study were students of Vocational High School (SMK) 9 Padang, particularly those in the tenth grade. The data were collected by using purposive random sampling technique. The result of this research is a product of an authentic assessment model that will be used by vocational English teachers in the ETP learning process in the classroom.
\end{abstract}

Keywords: Student Speaking Skill; Integration Technology; Vocational High School

\section{Introduction}

The term "assessment" is closely related to a test that is conducted in the classroom where the setting and scenario are decided by the teacher. Students, in this case, will follow what the teacher instructed them to do like doing dialogue, drama or other kind of activities where the situation is already designed. The assessment is usually done in the classroom and being watched by other learners in the classroom too. This kind of assessment is likely to be artificial and does not reflect language use in real life (Brown, 2004). What learners learn in the classroom are expected to be able to prepare them to communicate in real-life communication in the future. This condition is also addressed to vocational students who are prepared to directly work after graduating from vocational high school. The assessment is designed by integrating it with technology that is very closed with current world. When the students want to do the test, the teacher can conduct it by asking the students to record it and then post it in their social media. Beside familiarize the students with the real communication outside how people are currently communicating, they will be used to the technology and also social media that can help them to connect with the outside world. 
In vocational high school setting, the graduates are prepared to be able to work right away after graduating from schools. Those who are majoring in culinary, for example, are prepared to be the real chef in restaurants or five-stars hotels. Then, those who are majoring in tourism are expected to be able to work in tourism industry in the future. In West Sumatera, where tourism becomes one of the most crucial sectors, the tourism students are expected to be able to directly take role in supporting and promoting the tourism of this region once they have finished their study. This is why the learning and assessment need to be very authentic and, in this case, learners are really assessed for the kind of language they will really use in their workplace in the future. Meanwhile, to date, it is tangible that there is still a gap between how the current language assessment is conducted and how it is supposed to be done. Language assessment in vocational schools are mostly still held in a designed setting in the classroom, while it is supposed to be done in a more authentic way in order to equip the learners with proficient communication skill to set them ready for their future work later on. Throughout this study, the practicality and feasibility of the authentic assessment in vocational high school will be examined, especially for those who are majoring in tourism. To get it more accurate, the data is collected through online questionnaire.

\section{Methodology}

This research utilizes research and development model (R\&D) and uses ADDIE model (analyze, design, develop, implement and evaluate) that is done in Vocational High School (SMK 9) Padang, Indonesia. Firstly, the data was collected by using online questionnaire and participated by 37 students all together. The participants are majoring in tourism and ranging from the first to the third grade. Then, after the data from questionnaire is collected, the data is analyzed and described to get the needs analysis. After that, the information from the questionnaire is developed to make a model. The model, later on, will be developed by the researcher. Next, the model will be implemented and finally will be evaluated by students, teachers and experts to see whether the proposed model works well or not. More about ADDIE model will be explained as follows:

\section{a. Analyze (Analysis)}

At this stage, the researcher analyzes the process. Researchers will collect several required documents, such as students learning outcomes, materials or teaching materials, and students learning outcomes for speaking skills. At this stage the researcher also analyzes the lesson plans made by the teacher. All documents were photocopied and analyzed. Then, the researcher will also interview the teacher. The purpose of the interview is to find out how teachers assess students and what teachers need in authentic assessment methods. The next process is for researchers to distribute questionnaires to students. This questionnaire aims to know about lack, want, and necessity. The result of the interviews and questionnaires will be analyzed by the researcher together with all other supporting documents.

\section{b. Design}

At this stage, the researcher will create a prototype of the authentic assessment method. The researcher will design a suitable assessment method for the speaking or speaking skills of the students. The authentic assessment method is designed based on the results of interviews, the needs of students and teachers and the results of all document analysis. In designing the 
authentic assessment method, the researcher also refers to the syllabus and curriculum used in the SMKN 9 Padang school.

\section{c. Develop}

In the third step, the researcher will develop a model of the authentic assessment method for speaking or the speaking skills of the Tourism Vocational School students. Develop an authentic assessment method based on the prototype that was made in the previous stage.

\section{d. Implement}

At this implementation stage, the researcher will ask the teacher to use authentic assessment methods in the classroom when teaching speaking. Researchers will provide an explanation of the authentic assessment methods that have been developed. This stage aims to see the implementation of the product that has been developed. To find practicality or the implementation of the products that have been developed, researchers will ask teachers and students opinion through practicality checklists.

\section{e. Evaluation}

Evaluation is the last stage of the ADDIE Model. There are two types of evaluation, namely formative evaluation and summative evaluation. Formative evaluation was carried out since the researcher used the ADDIE model, this evaluation was carried out at each stage. Summative evaluation performed at the end of all stages in the development of the authentic assessment method. Below is the flow of Research and Development (R and D) research.

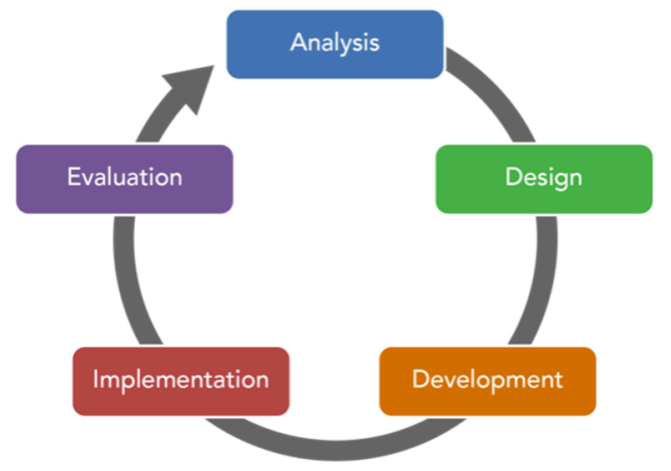

Figure 1. ADDIE Model

\subsection{Subject}

The subject of this study consisted of 37 students from SMK 9 Padang, West Sumatera, majoring in tourism study. They were boys and girls ranging from the first grade up to the third grade. The data were collected within four months, since March until June 2020. The students mostly have learned English for more than 9 years in total. As they are studying in tourism study, the majority of the students plan to work in tourism industry once they are graduated from school later on in the future.

\subsection{Data}

The data were collected by using online questionnaire that was distributed to the students who participated in this research. At the beginning, the data were calculated. After that, the 
collected data were analyzed and then conclusion is made in order to proceed to the next research process. In general, the data tell about what the students need in the learning and the assessment process in order to achieve the learning outcomes that has been set since the very first place.

\section{Result and Discussion}

The following explanation describes about the needs analysis received from the questionnaire given to the 37 students. It will explain how the current speaking assessment is done and how they think the ideal should be. The result of this research tells that

\subsection{The speaking assessment should be relevant with communication demand on daily life}

The survey revealed that the students agree to say that the assessment should be in line with the skills that will be needed in their daily life in the future. It can be seen from the chart below that $58.3 \%$ of the students agreed with this argument. Moreover, there are $36.1 \%$ (13 students) of the students who were very agree with this idea. Meanwhile, there was only little percentage of the students who do not agree with this idea (shown in the yellow part of the chart). It indicated that although they might have not really informed about this earlier, the students already had good perspective on how the assessment should be done.

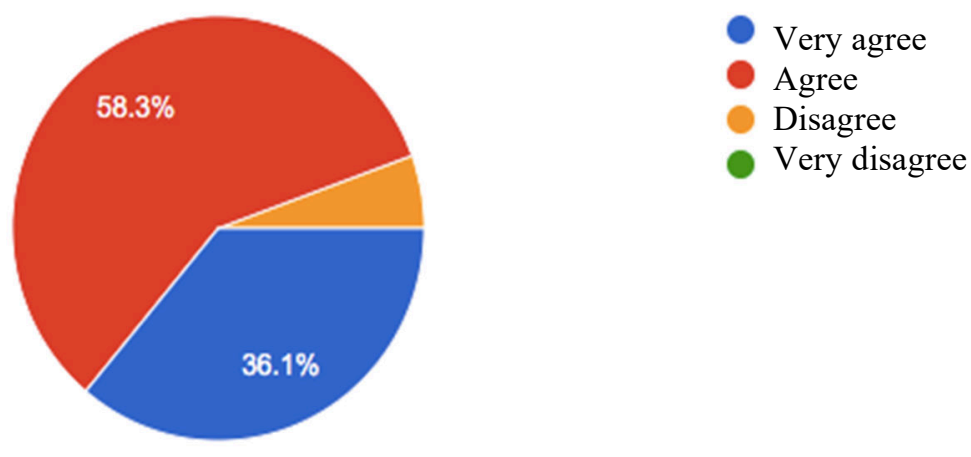

Figure 2. Survey results

\subsection{Techers should give clear marking criteria to the students}

As explained above, marking criteria in authentic assessment should be made clear so that students can get clear picture on what will be assessed during the test. The marking criteria consists of assessing grammar, vocabulary, pronunciation and many other linguistic components that should be attained in speaking assessment. The data showed that there were $(66.7 \%)$ or 24 voters agree to this. Meanwhile, the other $(30.6 \%)$ upgrade their choice by deciding to strongly agree with this. The illustration can be seen in the chart below: 

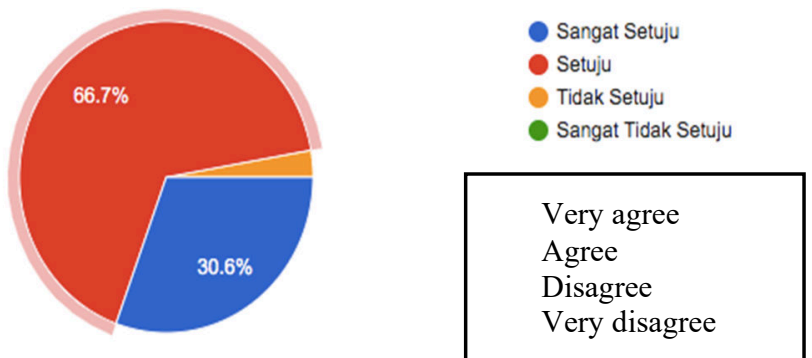

Figure. 2

Clear assessment standards in English assessments can help the students to understand the test better. Koshy (2009) concluded that it is very important for a teacher to determine the methods used to teach and assess their students work in line with predetermined goals from the start. Clear assessment criteria, according to Dunn (2004), can increase the validity and reliability of an assessment process

\subsection{Teachers better use authentic assessment to assess students' speaking ability}

There were $62.9 \%$ of the students who agree with this idea. This indicated that the students also want to demonstrate what they have learned into real-life practice. The previous data also showed that $71.4 \%$ students agree to say that they want the assessment to be done in outside of the classroom too. This implied that the students will be very enthusiastic if teachers bring them out to do the authentic practice which resemble daily life interaction that people normally do in their real life.

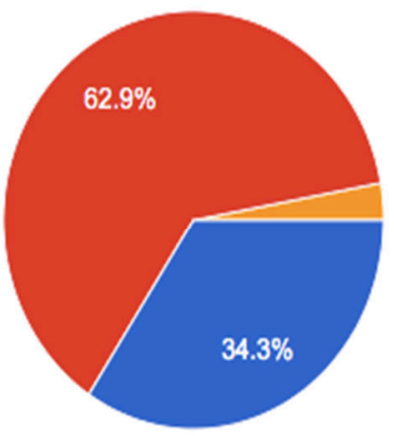

Very agree

Agree

Disagree

Very disagree

Figure. 3

This finding told us that paper-based exam is no longer relevant to be done in speaking class since that type of the test is very conventional. Instead, the test here is expected to enable students to really demonstrate their communicative skills by using logically-correct language to do so.

\subsection{Topic for speaking assessment should be close with learners' world}


The data below revealed that the students agreed to say that the assessment should be in line with the skills that will be needed in their daily life in the future. It can be seen from the graph below that $58.3 \%$ of students agree with this argument. In addition, there were $36.1 \%$ (13 students) who strongly agree with this idea. Sheils (2011) explains that in carrying out an English assessment, teachers must pay attention to the situational authenticity aspect of the assessment. This aspect is where the assessment material presented to students represents the use of language commonly used in everyday conversation. This is where the teacher is tasked with being able to adjust what is taught and tested with what is needed by students in daily interactions with the people around them. In other words, what is taught and tested should be able to help students communicate better in their real social environment in the real world.
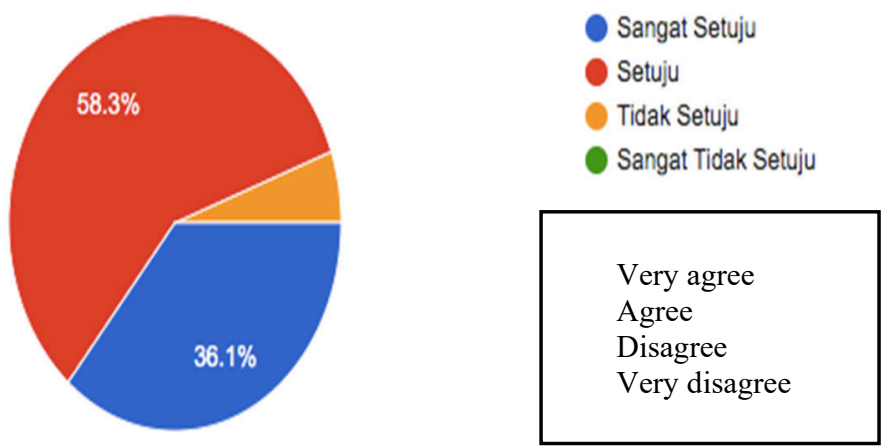

Figure. 4

It can be seen from the data below that the number of students who agree with the statement are big enough to be recommended to teachers and stake holders at school. Therefore, it is expected that the teachers can start to relate what they teach and test in the classroom are in line with what the students need in the real life in the future.

\subsection{The topics used in the speaking assessment should be close to student life and can improve the students' speaking ability in everyday life}

The results of the data collection above show very interesting numbers where the results of the questionnaire are only divided into two points, namely strongly agree $(40 \%)$ and agree $(60 \%)$. From the data above, it can be concluded that students have high hopes that what is tested in the speaking test is something they can connect with their daily experiences and needs. This is in line with the opinion of Shiels (2011) above which states that the designed exam must be adapted to the conditions and needs of students. Then, it is also hoped that learning can improve the students' speaking skills in the future. This can be seen in the results of the questionnaire which showed that $55.9 \%$ of students agreed that what was tested in the classroom could also support students' original communication skill.

\subsection{Speaking Assessment Should Support Students' Ability to Communicate with Foreign Tourists}

In speaking learning, it is expected that the speaking assessment process held at the end of the lesson can support students' ability to communicate with foreign parties later. This is because after graduating from the vocational school majoring in tourism, they can immediately work and get involved directly in developing tourism in West Sumatra. Therefore, good and fluent English proficiency is needed here. Interesting data can be seen from the data below which 
states that all students agree with this statement (50\% agree and another 50\% strongly agree).

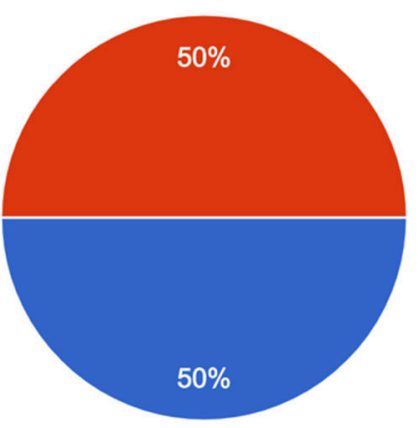

Very agree

Agree

Disagree

Very disagree

Figure. 10

With the increasing number of tourists entering Indonesia, especially West Sumatra, it is hoped that the graduates of the Tourism Vocational School are really ready to compete with good capacities, especially in terms of language.

\section{Conclusion}

The results of data collection in this study showed that the students believe that language tests were needed to measure students' achievement in the learning process, including speaking. This is in line with the opinion of Tosuncuoglu (2018) which explains the importance of assessment in learning English to make students know the ability they have. Furthermore, students agree that teachers need to make variations in the assessment process so that assessment activities become more interesting and less monotonous. Brown (1999) explains that authentic assessment can be carried out in various types of activities such as oral presentations, picture cued, interviews, role plays, pairs dialogue and student projects. This activity can be carried out both individually and in group.

Then, the research results also show that teachers must provide clear assessment standards to students so that students have clear guidelines in preparing and doing the test. This can be done by making a good assessment rubric and clear guidance for the students so they would be able to really prepare it before having the assessment. The results of further research explain that the teacher must make communicative and interesting English assessments. Then the speaking assessment model must be in accordance with what is needed in everyday life so that what is learned in the classroom can be useful for students' lives in the future. This is in line with the concept of authentic situation offered by Brown (2005) which stated that a test can be made communicative and can offer students the opportunity to meet and use the target language receptively and productively. Other results also show that the topics used in the speaking assessment should be close to the students' lives so they can easily relate with the test. Furthermore, it is hoped that graduates of the tourism department will be prepared to immediately contribute to the tourism sector in West Sumatra after completing college, so it must be ensured that what is tested and assessed while studying English at school are real and 
authentic enough for them. From the results above, it can be recommended that authentic assessment is needed in tshe learning process of English for Tourism Purposes (ETP) in schools so that later the desired targets can be achieved.

\section{References}

[1] Ajjawi, R., Tai, J., Huu Nghia, T. Le, Boud, D., Johnson, L., \& Patrick, C. J. (2020). Aligning assessment with the needs of work-integrated learning: the challenges of authentic assessment in a complex context. Assessment and Evaluation in Higher Education, 45(2), 304-316. https://doi.org/10.1080/02602938.2019.1639613

[2] Aksu Ataç, B. (2012). Foreign language teachers' attitude toward authentic assessment in language teaching. The Journal of Language and Linguistic Studies, 8 (2), 7-19. http://www.jlls.org/vol8no2/7-19.pdf

[3] Arnold, E. (1991). Authenticity revisited: How real is real?. English for Specific Purposes. 30(1), 237-144. https://doi.org/10.1016/0889-4906(91)90027-T

[4] Bachman, L. F. (1990). Fundamental considerations in language testing. Oxford: Oxford University Press

[5] Brown, H. Douglas (2004). Language assessment: Principles and classroom practices. White Plains, NY: Pearson Education.

[6] Brown, J. D. (2005). Testing in Language Programs: A Comprehensive Guide to English Language Assessment. McGraw: Hill College

[7] Dunn, K \& Mulvenon, S. (2009). A Critical Review of Research on Formative Assessment: The Limited Scientific Evidence of the Impact of Formative Assessment in Education. Practical Assessment, Research \& Evaluation. 14. 10.4324/9780203462041_chapter_1

[8] Field, R., Duffy, J., \& Huggins, A. (2013). Supporting transition to law school and student well-being: The role of professional legal identity. The International Journal of the First Year in Higher Education, 4(2). 15-25. https://doi.org/10.5204/intjfyhe.v4i2.167

[9] Fulcher, G. (2015). Assessing Second Language Speaking. Language Teaching, 48(02), 198-216.https://doi:10.1017/s0261444814000391

[10] Gulikers, J., Bastiaens, Th. \& Kirschner, P. (2004). A five-dimensional framework for authentic assessment, Educational Technology Research and Development, 52(3), 67-85. https://www.jstor.org/stable/30220391

[11] Hodges, D., Eames, C., \& Coll, R.K. (2014). Theoretical perspectives on assessment in cooperative education placements. Asia-Pacific Journal of Cooperative Education, 15(3), 189-207. https://eric.ed.gov/?id=EJ1113725

[12] Inayah, R \& Argawati, N (2019). Nurturing students' writing narrative interest through mind mapping and cooperative integrated reading and writing. Indonesian EFL Journal, 5(2), 121-130. https://doi.org/10.25134/iefli.v5i2.1781

[13] Karaoglu, S. (2008). Motivating Language Learners to Succeed. TESOL International Assosiation Journal. 5 (2). https://www.tesol.org

[14] Koshy, T. (2009). Catalan Numbers with Applications. Oxford: Oxford University Press

[15] Manual for Language Test and Development and Examining. (2011). Council of Europe. Strasbourg, NJ: Author 
[16] Moseley, D., Elliott, J., Gregson, M., \& Higgins, S. (2005). Thinking Skills Frameworks for Use in Education and Training. British Educational Research Journal, 31, 367-390. https://doi.org/10.1080/01411920500082219

[17] Mueller, J (2003). The Authentic assessment toolbox: Enhancing student learning through online faculty development. Journal of Online Learning and Teaching, 1(1), 1-7. https://jolt.merlot.org/documents/vol1 no1 mueller 001.pdf

[18] Nunan, D. (1999). Second language teaching \& learning. Boston, Mass: Heinle \& Heinle Publishers.

[19] Sadler, D.R. (2005). Interpretations of criteria-based assessment and grading in higher education. Assessment \& Evaluation in Higher Education. 30. 175-194. 10.1080/0260293042000264262

[20] Sahyoni, \& Zaim, M. (2017). Authentic assessment of speaking skill for Grade 1 Junior High School. Komposisi: Jurnal Pendidikan, Bahasa, dan Seni, 18(1), 15-26. https://10.24036/komposisi.v18i1.6509

[21] Tosuncuoglu, I. (2018). Importance of Assessment in ELT. Journal of Education and Training Studies. 6. 163. 10.11114/jets.v6i9.3443.

[22] Wiggins, Grant (1990). The Case for Authentic Assessment. Practical Assessment, Research, and Evaluation: 2 (2), 1-4. https://doi.org/10.7275/ffb1-mm19 